\title{
日本語の辞書における文法的情報について An Analysis of Grammatical Information in Japanese Language Dictionaries
}

王崗/方韻 深圳大学/香港中文大学

\section{要旨}

日本語の辞書において、さまざまな言語的情報が盛り込まれている。その中で、語の用法に関連 する文法的情報も取り入れられるはずであるが、一部の辞書にはそれが久けている。例えば、用言 の活用形については、ごく一部の辞書に、その活用形の列記がなされているが、ほかの辞書ではそ ういうところを完全に無視しているように見受けられる。似たケースは、見出し語の表現やその注 意事項、派生語などの情報提供の場合にもある。学習者の立場からみれば、日本語の文法的情報が 日本語の学習に結び付くことがあると思われる。従って、これから新しい日本語の辞書を編集した り、特に学習者向けの辞書を作成したりする際には、これまでの辞書にみられる情報明示の不足な ところを意識し、それを辞書に添付、提示するほうが望ましいと考えられる。

キーワード：

日本語の辞書、文法的情報、学習者、日本語の学習 


\section{日本語の辞書における文法的情報について}

王崗/方韻

深圳大学/香港中文大学

\section{1.はじめに}

辞書本来の用途といえば、語の意味と用法についての指示にあると考えられる。言い換えれば、 多くの人は、ある語の意味や使い方を正確に知りたいときに、辞書を引くのである。しかし、現在 の多くの辞書を見比べたところ、語の意味の説明に重きを置いており、その用法などについては十 分に示されていないことに気がついている。日本語の辞書について、これまでは、姫野昌子 （2006）、沖森卓也（2006）などは、語のつながりや意味記述に関する議論があったが、語の使い 方に大きく関わる文法的部分について詳しい検討はしていない。成人の日本語話者にとっては、辞 書に文法的情報の記載が余計なものになるかもしれないが、日本語を学ぶ学習者にしてみれば、そ の情報が日本語習得に結び付くことが多いと考えられる。では、現在の日本語の辞書 ${ }^{1}$ において、ど のような文法的情報がみられるまたはみられないのだろうか。そして日本語の学習に必要な情報は 何であろうか。本稿では、学習者の立場からそれを取り上げ、検討する。

\section{2. 用言の活用形の情報}

辞書は、文法指導書ではないので、用言の活用形の列記が果して必要なのだろうかと疑われるか もしれないが、実際、初・中級レベルの学習者にとって、その活用形はかなり難しい学習内容であ る。それを正確にしかも自由自在に使い慣れるまでは、繰り返しの練習や記憶が必要不可欠である。 現在の辞書には、その活用形を積極的に取り扱うものはあるが、あまり関心を示さないものもある。 以下、 2 点に分けて分析を進める。

\section{1 活用形があまり明示されないケース}

辞書に用言の活用形を示したほうが望ましいと本稿で主張しているが、一部の辞書ではそれに関 わる有力な情報をあまり多く提供していない。次の辞書例を参照されたい。

（1）しらじらしい【白白しい】1《見えすいた》・明显的 mingxian de ー 世辞・明显的恭维 mingxiande gongwei $\boldsymbol{2}$ 《興ざめな》 $\sim$ 空気が流れる・气氛令人掃興 qifen ling ren saoxing（『外研社一三省堂日漢漢日詞典』p. 272） 
（2）ふる・えるふらる【震える】【自ア下一』フルエル【コトニ（デ）〕田細かく摇れ動く。振動す る。眰ガラス空が車の振動で震える/風に震える木の葉。2 寒さや恐怖、緊張などで身体や 身体の一部、声などが小刻みに摇れ動く。圆文字を書く手が震える/こわくて足ががくがく 震えた/怒りで声が震える。

(『小学館 日本語新辞典』p. 1503)

（1）では、見出し語の形容詞「しらじらしい」に対して、用例にその連体形、すなわち基本形の みが使用されているが、語釈に当語の活用形に関する記述は見当たらない。（2）には、動詞の「ふ るえる」に対して、連用形の「震え（た）」と、基本形に相当する終止形、連体形のみが用例に採 用され、そのほかの活用形に関する提示も記述もなされていない。

\section{2 活用形が比較的多く示されるヶース}

2.1 にみられる問題点を補う意味で、一部の辞書で、用言の活用形を上記の（1）と（2）に比べ、 比較的詳しく示すことが見受けられる。その示し方は、辞書によってさまざまであるが、全体的に みれば、おおよそ 2 通りになるだろうと思われる。1つは、次の（3）のように、見出し語の下に、 「カ（コ）・キ・（イ）・ク・ク・ケ・ケ」と動詞の活用形を小字で列記することである。

（3）あ・く【開く】（自五）カ（コ）・キ・（イ）・ク・ク・ケ・ケ (1)閉じていたものがひら く。「戸がー」乡閉まる(2)（停止しているものが）活動する。「幕がー（=上演が始ま

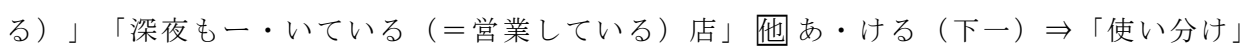

(『旺文社国語辞典（第十版）』p. 27)

ただ、こういう記述の方法は、果たして効果があるのか疑問になる。というのは、そこまで留意 する学習者が少ないし、その形式自体を知らない学習者も少なくないからである。また、形容詞、 形容動詞などについて、そういう表示では無理なところがあることも問題になる。

もう1つは、次の（4）のように、用例中に用言の活用形を示す方法である。

（4）なつかし・い【懐かしい】ナツカシイ以前にあったことなどが思いだされて、忍がひか れる。田懷戀; 春戀; 令人想念。罒 yearn for ; nostalgic; dear.

年年をとると子供のころのことがなつかしくなる/上了年紀就令人想念起孩提時代的事情。 江10年ぶりに山田さんに会ってなつかしかった/隔了十年與山田君見面, 真是令人懷念。 污なつかしいふるさと/令人眷戀的故郷。

（『易懂日漢辭典（日本語を学ぶ人の辞典）』p. 1016）

（4）では、形容詞「なつかしい」の連用形「く」と「かっ（た）」、そして連体形を用例に採用 している。先の（1）に比べ、活用形が 2 つ多く増えているが、全体的には、活用形の記述がまだ不 
十分であると言わざるを得ない。

実際、本稿の著者は、手元に集めてある 10 数冊の辞書を一通り調べたが、（4）のような方法で すべての活用形を扱う用例は、いまだに 1 も見当たっていない。ということは、（3）を除けば、 ほとんどの辞書作成者は、そもそも用例や語䣋に用言の活用形を明示しょうという意識自体も持っ ていないということが分かってくる。

また、現在の辞書には、先の（1）と（2）もそうであるが、（3）と（4）にみられるように、用 言の基本形そのままを使用するものが多い。これは、おそらく用例の作りやすさを図るためだとい えるだろう。しかし、こういう短絡的やり方は、中級レベル以下の学習者への配慮に欠けているよ うに思われる。よって、これからの辞書、特に初・中級レベルの学習者向けのものには、たとえ全 用言の全活用形でなくてもいいが、それらを関連する各語の用例に分散表出したほうが望ましくな るだろう。こうして、動詞、形容詞、形容動詞といった用言を検索する学習者は、辞書の中に比較 的頻繁に出ている活用形を目にしていて、無意識のうちに認知し、把握していく可能性が高いと容 易に想像される。

\section{3. 表現の情報}

\section{1 一般表現の場合}

日常生活において、話し手が自分の意思を伝えるために、さまざまな表現形式を用いる。それは、 母語話者にはごく自然な言語交流の能力であるが、学習者には身に付けにくい能力の一つに数えら れる。学習者と母語話者によるコミュニケーションに支障がしょっちゅう生じるのはそのためであ ろう。それを改善するためには、日ごろの訓練や学習が必要になる。学習者に身近な存在である辞 書に、日本語の表現に関する説明や提示を施すのは、いわば一種の学習になり、いざという時の参 考にもなる。しかし、現在の辞書には、そういう取り組みなどがめったに行われていないものがあ る。次のようである。

（5）どうてき楝【動的】〔ナ】動きに富んでいるさま。また、生き生きしているさま。 ダイナミック。@静的（『集英社 国語辞典（机上版）』p. 1235）

（6）かんどう【感動】gandong（感動）\|魯迅の《狂人日記》を読んで梁く〜した. kanle Lu Xun de 《kuangren Riji》hen shou gandong (看了魯迅的《狂人日記》很受 感動）.

$\|$ 彼の演説は聴衆に大きな〜を与えた.

ta de jiangyan geile tingzhong ji da de gandong（他的講演給了听众极大的感 动).

$\| \sim$ 詞 gan- $\operatorname{tanci}($ 感嘆詞）／ tanci（嘆詞）。（『岩波日中辞典』p. 273） 
（7）ところ一せま・し【所狭し】（形ク）場所が狭く感じられる。余地がない。穿屈だ。 narrow； crowded 用例商品が一と並べられている。

（『講談社 カラー版 日本語大辞典（第二版）』p. 1547)

（5）には、語釈のみがみられ、表現上の注意点どころか、用例さえも出されていない。（6）に は、見出し語の動詞と名詞の用法例が出ているが、中国語話者の間違いやすいとされる「〜に感動 する」や「感動的な」というような表現情報が久けている。（7）では、「ク」活用の（文語）形容 詞と書いてあるが、日常的表現であるかどうかについての記述もないし、現代日本語と文語の形容 詞の用法のいずれにも該当しない「〜ところせましと並べられている」についての説明も載ってい ない。

上記の辞書例に対して、次の辞書には、比較的多くの情報が提示されている。

（8）いそがし・い【忙しい】《形》(1用事が多くて他のことにかまっていられない。 多忙だ。「仕事で一」「遊び回るのに一」 2落ち着きがなくせかせかと動き回るさま。 せわしい。せわしない。「一性分の人」「車が一・く行き来している」䦜 击(2)に、言い切りの言い方はない。・「急ぐ」と同語源。派生-げ/-さ/ーが・る

「忙しい」の比喻表現

・目が回る[猫の手も借りたい／席の暖まる暇もない/てんてこ舞する/きりきり舞いす る/体が二つあっても足りない]ほど忙しい（略）

（『明鏡国語辞典 携帯版』p. 96)

アッ゙

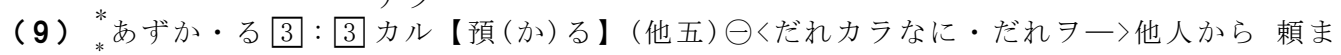
れたものの責任をもって保管(保護)する。「隣の子供を一/患者の生命を一」きくなにヨ 一事務の処理やめんどうな出来事の始末を任される。「家計を一/けんかを一〔（／仲裁す る〕/勝負を一〔=保留する〕/氏名はしばらく預かって〔＝公表を保留して〕おく」［？ 預かり

(『新明解国語辞典 第六版』p. 23)

（8）には、「〜で忙しい」、「〜に忙しい」という表現情報のほかに、用法(2に「言い切りの言 い方はない」という提示がなされている。また、「忙しい」に関わる比喻表現という補足知識も紹 介されている。

（9）には、文字通り「だれカラなに・だれヨー」という表現形式が明示されている一方、「けん かをあずかる＝仲裁する」という表現上の意味対応も示されている。

（9）のように、用例にすでに明確に示されているものだが、なおかつ「だれカラなに・だれヨ 一」のような文型を提示すべきかどうかについて、議論する余地がまだある。とはいえ、スペース 
の許す限り、辞書に何らかの形で日本語表現の情報を示せば、単語検索の折に当語をめぐる用法や 表現を学習者に同時に吟味させるところで役立つものになる。

\section{2 類義表現の場合}

日本語を使うときに、学習者をしょっちゅう悩ませるのは、類義的表現の使い分けということだ ろう。日本語の類義表現に関する書物は、すでに数多く出版されているので、詳しい知識を知るた めにそのようなものを参考したりするのが習得を促すいい方法だといえる。ただ、問題なのは、そ のような本は概して学術色の濃厚なものが多いということにある。このため、このような指導書に は、一般の社会人学習者または初・中級レベルの学習者には読みづらいという嫌いが出てくるので ある。このような場合では、学習者に親しみやすい辞書に簡単で分かりやすい類義表現の情報を載 せれば、その日本語の学習を助ける可能性が高くなるものと考えられる。

現在のごく一部の辞書には、類義表現を取り入れているものがあるが、関心を示さないものも多 い。例えば、次の辞書には、それを取り上げていない。

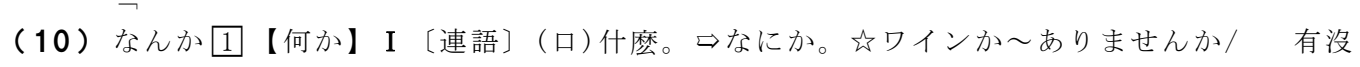
有酒什麼的?败花か〜を使って飾っている/用花什麼的裝飾著。II〔副詞〕（口）之類。马 など。えこれっぼちの困難〜、なんでもないでしょう/這點困難算不了什麼吧? うわたしは 政治的野心〜持っていない/我對政治之類沒啥野心。

(『修訂新版 新時代日 漢辭典』p. 1310)

（10）における「なんか」は、意味と用法において「なんて」に似ているところがある。しかし、 当の辞書では、そういった類義表現の使い分けを紹介していない。これに対して、次の辞書では、 類義的表現への解説がなされている²。

（11）だけ (1) (名詞、動詞と形容詞の基本形、形容動詞の「な」の形について）（1）も のごとをその程度や範囲内に限ることを表す。（略）畛「しか」も、ものごとを限定す る点で似ているが、「しか」が「教室に学生が 1 人しかいない」のように、いつも否定 のことばと一緒に使われるのに対して、「だけ」は「教室に学生が 1 人だけいる」と肯 定の形になる。「学生が 1 人だけいない」と言うこともあるが、このばあいは意味が違 って、ほかの学生はいるが、1人の学生だけがいないことになる。また、(1) (1) の改まっ た言い方は「のみ」。

（『易懂日漢辭典（日本語を学ぶ人の辞典）』p. 794-p. 795)

（11）では、見出し語の「だけ」に対して、参考知識として、「しか」との区別、「のみ」との 違いなどを記している。このような情報は、「だけ」を調べる学習者がそのついでに読み、参考に 
できるもので、一種辞書編集上の工夫の現われであるといっていいだろう。

もちろん、辞書はあくまで語が中心になるため、日本語の表現をところどころに明示することは 基本的に好ましくないと考えられる。とはいうものの、紙幅の許す限り、常用の表現、簡単にまと められる表現、比較的重要な表現などについては、辞書に適宜解説を施すほうが望ましいだろう。

\section{4. 派生語などの情報}

辞書における派生語などの情報は、上級レベルの学習者には基本的に無用だと思うが、初・中級 レベルの学習者には参考になるときがある。しかし、次の（12）にみられるように、そういう情報 を載せない辞書は少なくはない。

（12）てばやい【手早い】麻利 mali, 敏捷 minjie.川実に〜衫/真麻利呀. \|身支度を手早くす ませる/很快地打扮 daban 好. || 手早く仕事をかたづける/麻利地「干 gan 完工作〔完成任 务]。(『日中辞典』p. 1299)

（12）にひきかえ、次の（13）と（14）は、形容詞の派生語、動詞の名詞形などを提示している ため、評価すべきものである。

（13）•とぼしーい田㘠【乏しい】（形）(1)不足している。「才能が一」「一魅力」(2)貧しい。 「一生活」っ「ともしい」ともいう。图一さ形動一げ図とぼーし〔シク〕

（『集英社 国語辞典（机上版）』p. 1268）

（14）［うが・つ(・穿つ）］（動五）１穴をあける。また、貫きとおす。貫く。「雨だれ、石 を穿つ」「トンネをうがつ」２隠れた事情や細かい事実、また、世態や人情の機微を指 摘する。「なかなか穿ったことを言う「穿った見方」3袴や和服、履物などを身につけ

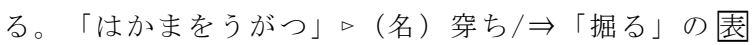

（『現代国語例解辞典（第四版』p. 107）

派生語などの情報は多くの場合、辞書に簡単に列記するだけでいいので、辞書のスペースをあま り占めないで済むわけである。この意味で、これからの辞書には、そのような情報を可能な限り添 付するほうが望ましいだろう。

\section{5. おわりに}

ここまでは、中国内外の日本語の辞書にみられる文法的情報について検討してきた。学習者の立 場からみれば、現在の辞書には、日本語の学習に結びつく情報が比較的多く提供されるものはある が、それがかなり欠けているものもあると確認できている。学習者による日本語の学習において、 常備品ともいえる辞書には、1つでも多く有用な情報を提示寸れば、時に学習者の大きな助けになる ことを本稿においては主張している。 
また、本稿で明らかにしたように、いままでの多くの辞書には語の意味に対する説明が充実して いるが、その用法に対する提示がいくらか欠けているところがある。従って、これからの新しい日 本語の辞書、とくに学習者のための辞書作成を手がける際に、いかに有益な知識を利用者に多く伝 えるかなどを考える必要がある。

\section{注}

（1）本稿で取り扱う日本語の辞書は、日本または中国にいる日本語学習者が使うと思われるものに 集中する。しかも、それは汎用的辞書を指し、「類義語辞典」や「慣用句辞典」のような専用 的ものは検討の範囲外とする。また、各辞書を引用する際に、パソコンの操作機能の制限でそ の字体や書式などを一部調整することがある。

（2）当の辞書には、すべての漢字に振り仮名がついているが、紙幅の関係でここでそれを略してお $<。$

\section{用例出典}

梅棹忠夫ほか（1995）『講談社カラー版 日本語大辞典（第二版）』東京：講談社

遠藤織枝（編輯主幹）/于乃明（等譯）（2007）『易懂日漢辭典（日本語を学ぶ人の辞典）』台北：

大新書局

北原保雄（2003）『明鏡国語辞典携帯版』東京：大修館書店

倉石武四郎ほか（1986）『岩波日中辞典』北京：商务印書馆，東京：岩波書店

小学館辞典編集部（2006）『現代国語例解辞典（第四版』東京：小学館

杉本达夫ほか (2002) 『外研社一三省堂日漢漢日詞典』北京 : 外語教学与研究出版社

陳伯陶（2003）『修訂新版 新時代日漢辭典』台北：大新書局

対外経済貿易大学/商務印書館/小学館（共同編集）（2002）『日中辞典』北京：対外経済貿易大

学, 北京: 商務印書館, 東京: 小学館

松井栄一（2005）『小学館 日本語新辞典』東京：小学館

松村明ほか（2005）『旺文社国語辞典（第十版）』東京：旺文社

森岡健二ほか（1993）『集英社 国語辞典（机上版）』東京：集英社

山田忠雄ほか（2005）『新明解国語辞典 第六版』東京：三省堂

\section{参考文献}

姫野昌子 (2006)「学習者のためのコロケーション辞典一『日本語表現活用辞典』の作成に際して

一」『日本語学』 7 月号、東京 : 明治書院、40-50

沖森卓也（2006）「国語辞典の意味記述一語䣋の示し方を中心に一」倉島節尚編『日本語辞書学の

構築』東京：おうふう、519-532 